\title{
Folklor Lisan Dendang pada Malam Bimbang Gedang Tepuk Tari Adat Perkawinan Kota Bengkulu
}

\author{
Eli Diana, \& Dhanu Ario Putra \\ Universitas Dehasen Bengkulu \\ elidiana@unived.ac.id; dhanryu@unived.ac.id
}

\begin{abstract}
How to cite (in APA Style): Diana, E. \& Putra, D.A. (2019). Folklor Lisan Dendang pada Malam Bimbang Gedang Tepuk Tari Adat Perkawinan Kota Bengkulu. Jurnal Pendidikan Bahasa dan Sastra, 20(1), 84-94 . DOI: https://doi.org/10.17509/bs_jpbsp.v20i1.25974
\end{abstract}

Article History: Received (13 July 2019); Revised (11 October 2019); Accepted (1 April 2020) Journal homepage: http://ejournal.upi.edu./index.php/BS_JPBSP

\begin{abstract}
Abstrak: Dendang merupakan salah satu sastra lisan masyarakat kota Bengkulu. Penelitian ini bertujuan untuk mendeskripsikan dendang Tepuk Tari dalam adat perkawinan kota Bengkulu, bentuk, fungsi, dan nilai yang terkandung di dalamnya. Metode yang digunakan dalam penelitian ini adalah metode deskriptif kualitatif dengan menggunakan teknik rekaman, wawancara, menyimak, dan mencatat. Informan ditentukan dengan menggunakan snowball sampling. Data utama dalam penelitian ini adalah syair dendang yang diambil dari video rekaman dendang dan dilengkapi dengan hasil wawancara dengan beberapa informan. Adat dendang ini diisi dengan penampilan tujuh tarian adat kota Bengkulu yang diiringi dengan alunan musik tradisional Bengkulu serta pantun-pantun. Adapun pantun yang digunakan terdiri atas: 1) pantun biasa, dan 2) talibun. Fungsi dendang tersebut adalah sebagai; 1) sarana hiburan, 2) jati diri masyarakat, 3) kritik sosial, dan 4) sarana mendidik dan memiliki nilai: 1) filosofis, 2) religi, dan 3) sosiologis.
\end{abstract}

Kata kunci: folklor lisan; adat perkawinan; dendang

\section{Oral Folklore of Dendang at Malam Bimbang Gedang Tepuk Tari in The Marriage Customs of Bengkulu City}

\begin{abstract}
Dendang is one of the oral folklores of Bengkulu city. This study aims to describe dendang Tepuk Tari in the marriage customs of Bengkulu city, the form, function, and values. The method used in this research is descriptive qualitative method using recording techniques, interviews, listening, and taking notes and the Snowball sampling technique. The main data in this study are the chanting poems taken from the video footage that was sung and equipped with the results of interviews with several informants. This traditional dance is filled with the performance of seven traditional dances accompanied by Bengkulu traditional music and rhymes. The rhyme used consists of: 1) regular rhyme, and 2) talibun. The functions of the dendang are as; 1) entertainment facilities, 2) community identity, 3) social criticism, and 4) educational facilities, and it contains the values of: 1) philosophical, 2) religion, and 3) sociological.
\end{abstract}

Keywords: oral folklore; marriage customs; dendang 


\section{PENDAHULUAN}

Karya sastra berkembang pesat seiring dengan berkembangnya fenomenafenomena yang muncul dalam kehidupan manusia. Ungkapan perasaan dan pikiran tertuang bebas dalam karya sastra, baik secara tertulis maupun lisan. Sastra lisan (Literature transmitted orally atau unwritten literature) merupakan jenis karya sastra yang penyebarannya meluas dari mulut ke mulut atau secara turun temurun yang berbeda dari sastra tulis yang tersebar secara tertulis atau cetak (Astika \& Yasa, 2014, p.2). Sastra lisan (folklore) merupakan sastra verbal yang merupakan gambaran budaya suatu masyarakat atau komunitas secara tradisional yang tidak diketahui siapa pengarangnya secara pasti. Folklor lisan ini dapat berupa nyanyian-nyanyian tradisional, legenda, dongeng, sindiran, teka-teki, pantun, dan sastra lisan warisan budaya lainnya.

Folklor lisan erat kaitannya dengan kebudayaan daerah. Kebudayaan daerah merupakan sumber lahirnya folklor lisan yang menggambarkan corak dan ragam budaya khas suatu daerah, termasuk salah satunya adalah budaya dalam adat perkawinan. Tiap daerah memiliki adat perkawinan yang beraneka ragam. Hal ini merupakan salah satu topik yang banyak diminati oleh para peneliti sastra baik dari dalam maupun luar negeri. Masing-masing daerah memiliki ritual-ritual, aturan-aturan, kepercayaan-kepercayaan, serta tata cara yang beragam sehingga menarik dan unik untuk dikaji. Hal ini dilakukan dalam rangka untuk melestarikan warisan budaya daerah agar tidak punah oleh perkembangan zaman. Dalam upacara adat perkawinan tersebut juga sering dijumpai budaya nyanyian-nyanyian, pantun, syair, pepatah, dan sindiran yang muncul dalam salah satu atau beberapa agenda acara yang merupakan warisan budaya daerah. Dalam penelitiannya Waskita, et al., (2011), sastra lisan merupakan strategi berperan sebagai strategi pertahanan nasional di Pelabuhan Ratu.
Adat istiadat merupakan wujud ideal dari kebudayaan. Effendi, et al. (1998,p.67) menyebutkan bahwa adat merupakan nilai-nilai budaya, norma-norma hukum, pandangan hidup dan cita-cita, pengetahuan dan keyakinan. Ada suatu sanksi yang akan berlaku jika nilai-nilai ini dilanggar, yakni disebut dengan sanksi adat.

Adat perkawinan di Indonesia diatur dalam Undang-Undang No 1. Tahun 1974 (Asri, 2008,p.17) yang menyebutkan bahwa perkawinan adalah sebuah ikatan lahir batin antara seorang pria dengan seorang wanita sebagai suami isteri untuk membentuk keluarga yang bahagia dan kekal yang didasarkan pada Ketuhanan Yang Maha Esa. Dari perspektif budaya Melayu (nusantara), upacara perkawinan terikat dengan adat istiadat. Hal ini tetap dijaga dengan pertimbangan bahwa perkawinan dengan adat merupakan ajang hadirnya keluarga besar, masyarakat, majelis dan pemuka agama serta adat untuk memberikan restu kepada kedua mempelai. Perkawinan yang tidak dilandasi dengan adat cenderung mendapatkan kesan yang negatif terhadap suatu perkawinan (Takari, 2014,p.76-77).

Dalam hal perkawinan, kota Bengkulu memiliki adat istiadat sendiri yang merupakan warisan budaya leluhur. Namun tetap memerlukan tiga masa proses seperti adat budaya suku lain, yaitu (a) pendekatan terhadap calon pasangan hidup dan persiapan, (b) upacara perkawinan itu sendiri, dan (c) berbagai aktivitas selepas upacara perkawinan yang disebut dengan praupacara perkawinan, upacara perkawinan, dan pasca upacara perkawinan (Takari, 2014,p.107). Marwati (2017,p.10) menemukan bahwa adat perkawinan masyarakat Bajo di Pulau Balu terdiri atas melamar, pertemuan para tokoh adat, memanggil secara langsung, peminangan, pernikahan, dan mengantar pengantin.

Menurut Peraturan Daerah Kota Bengkulu Bab I tentang Bimbang dan Ritual Kemantin Pasal 17 tentang Upacara Adat Nikah (2005,p.19-28), peresmian perkawinan di kota Bengkulu disebut 
dengan bimbang perkawinan yang dilaksanakan paling lambat 3 bulan setelah bertunangan. Adapun acara kegiatannya adalah: 1) mufakat adik sanak atau disebut berasan, yakni musyawarah mufakat untuk keluarga, 2) mendirikan pengunjung (tegak pengunjung/tarub), yakni mendirikan tempat pelaksanaan peresmian perkawinan yang biasanya dilakukan 1 atau 3 hari setelah berasan, 3) berdabung (mengikir gigi), yakni calon pengantin perempuan membersihkan gigi dengan cara mengikir gigi, dan ritual ini diawali dengan kesenian gendang dan serunai, 4) mandi harum, yakni memandikan pengantin perempuan mulai dari mencukur rambut disekitar dahi, meratakan anak rambut, ikatan sanggul dan merias wajah, 5) inai curi, yakni pengantin wanita memasang pewarna kuku kaki dan tangan (warna merah) menggunakan daun pacar atau inai yang digiling, ritual ini berbarengan dengan inai bedendang, 6) Belarak/Mufakat Rajo Penghulu (sesi meminjam adat), yakni kedua mempelai dengan menggunakan pakaian adat pengantin kota Bengkulu diarak di sekitar tempat tinggal, 7) malam bimbang gedang (hiburan dan tarian), 8) akad nikah yang disertai dengan berzikir (kitab berzanji dengan lagu khas menggunakan gendang dan rebana), 9) pengantin bercampur (duduk dipelaminan), 10) malam bergamot, yakni pertunjukan seni dan tari-tarian, 11) menjalang, yakni pengantin yang sudah sah menikah mengunjungi kerabat dan keluarga (keluarga sendiri ataupun besan) untuk memperkenalkan diri serta mengetahui tuturan (panggilan) 12) membuka tarup/pengujung, yakni bergotong-royong membongkar tempat peresmian perkawinan, dan 13) pengembalian adat bimbang, yakni pengembalian peralatan-peralatan yang dipinjam untuk pelaksanaan perkawinan.

Dalam buku Adat dan Upacara Perkawinan Daerah Bengkulu (1995, p.154), terdapat kesenian adat yang digunakan pada saat peresmian perkawinan, yang dikenal dengan malam bedendang. Kesenian ini diisi dengan dendang-dendang melayu Bengkulu dan tari dengan lagu-lagu khas dan dialek daerah Bengkulu. Dendang ini merupakan salah satu folklor lisan yang ada di Bengkulu. Acara bedendang ini dilakukan pada saat ritual inai curi dengan tari-tarian menggunakan pencak silat oleh sekelompok seniman kota Bengkulu, meliputi anak-anak, remaja dan dewasa.

Bengkulu adalah salah salah satu provinsi yang kental dengan adat istiadat dan ragam budaya, misalnya adat perkawinan. Namun dewasa ini, berdasarkan observasi awal, seiring dengan perkembangan zaman, adat perkawinan tersebut perlahan-lahan tergantikan dengan cara-cara perkawinan modern. Dan yang lebih memprihatinkan, banyak penduduk Bengkulu dewasa maupun anak-anak tidak memahami budaya ini. Kesenian khas ini perlu dilestarikan dan dibina untuk memperkaya perbendaharaan kebudayaan nasional dan untuk menghadapi globlalisasi yang masif dan sistemik.

Ada beberapa penelitian yang mengkaji tentang adat perkawinan. Namun mayoritas fokus kepada adat perkawinan di daerah-daerah (kabupaten) secara umum, yakni berisi tentang rangkaian adat pernikahan secara umum. Seperti penelitian Tarmizi (2010) yang meneliti tentang fungsi kesenian dendang perkawinan di kota Manna Bengkulu Selatan yang kemudian dilanjutkan pada tahun 2012 tentang tafsir nilai-nilai pantun dendang Suku Serawai kota Manna Bengkulu Selatan. Namun penelitianpenelitian tersebut hanya menganalisis dendang dari segi fisik bahasa tanpa menjabarkan prosesi dan tahapan-tahapan dari masing-masing dendang tanpa mengaitkannya dengan identitas masyarakatnya.

Penelitian berikutnya adalah penelitian tentang dendang Banjar Hulu oleh Marfuah (2014) yang menemukan kajian bentuk, makna, dan fungsi dendang Banjar Hulu. Kemudian Samsudin (2018) meneliti tentang upacara adat perkawinan di Bengkulu dari segi analisis filoso fis, nilai Islam dan kearifan lokal. Penelitian tersebut tidak fokus meneliti tentang dendang, melainkan upacara adat 
perkawinan secara keseluruhan.

Oleh karena itu, peneliti tertarik untuk mendeskripsikan serta menganalisis folklor lisan dendang pada malam Bimbang Gedang Tepuk Tari khas kota Bengkulu ini dengan harapan untuk memperkenalkan sekaligus mempromosikan budaya daerah kota Bengkulu kepada dunia. Penelitian ini bertujuan untuk mendeskripsikan tahapan prosesi dendang secara rinci dan mengkaji bentuk, fungsi, dan nilai dendang yang dihubungkan dengan adat budaya dan sosial masyarakat Bengkulu.

\section{METODE}

Penelitian tentang folklor lisan dendang adat perkawinan kota Bengkulu ini dilaksanakan di kota Bengkulu, tepatnya di Kelurahan Penurunan, salah satu kelurahan di Kecamatan Ratu Samban kota Bengkulu yang posisinya tidak jauh dari Pantai Panjang Bengkulu. Sebagian besar penduduknya adalah penduduk asli Bengkulu yang memiliki kontribusi besar dalam menyelenggarakan upacara-upacara adat di Bengkulu, misalnya perayaan tabot dan tradisi lainnya.

\section{METODE}

Penelitian ini merupakan penelitian deskriptif kualitatif, yakni mendeskripsikan data berdasarkan kenyataan-kenyataan secara objektif sesuai dengan data yang ditemukan di lapangan. Untuk menyibak fenomena budaya yang erat kaitannya dengan nilai-nilai kehidupan penduduk setempat, penelitian ini menggunakan teori Hermeneutika. Menurut Ricouer (2002; 2006), ada tiga level dalam Model Lingkaran Hermeneutika, yakni: a) Semantik, untuk menjelaskan makna sastra yang dilihat dari diksi, kalimat-kalimat, dan gaya bahasa, b) Refleksif, yakni tahap menemukan pemahaman secara komprehensif dengan menggunakan pendekatan etik dan emik, c) Eksistensial, yakni memaparkan hakikat pemahaman yang bersifat deep meaning. Sementara untuk mengkaji tentang fungsi dan nilai yang terdapat dalam dendang ini maka digunakan teori fungsi dari William R. Bascom dan Alan Dundes dalam Sudikan (2001) dan Danandjaja (1986) dan teori nilai dari Bertens (2004).
Data utama dalam penelitian ini adalah syair dalam dendang. Lalu diperkuat dengan hasil wawancara dengan beberapa informan yang dipilih dengan menggunakan snowball sampling, yakni dengan menemukan 1 orang informan sebagai juru kunci, lalu diperoleh informan-informan berikutnya dari infroman juru kunci. Informan yang akan dipilih dalam penelitian ini adalah seorang pemuka adat dan masyarakat, tokoh yang dituakan, penduduk asli dan dipercaya dapat memberikan data yang akurat, mengetahui dan berpengalaman banyak dalam adat dendang kota Bengkulu.

Adapun teknik pengumpulan data di antaranya melalui observasi, rekaman, wawancara dan dokumentasi Antara lain kegiatannya berupa,

1. Observasi

Pada tahap ini, peneliti melakukan pengamatan secara langsung di lapangan sebagai pengamat non-partisipan, mencatat temuan-temuan yang diperoleh di lapangan, dalam hal ini untuk mengetahui pelaku/pemain dendang, fasilitas yang digunakan, serta menyimak bentuk folklor lisan dendang Bengkulu.

2. Rekaman

Teknik rekaman ini dilakukan untuk meliput prosesi dendang dan untuk merekam syair-syair yang terdapat dalam dendang. Perekaman ini dilaksanakan selama beberapa kali dalam latihan sanggar dan prosesi dendang sebenarnya dalam upacara pernikahan di Bengkulu.

3. Wawancara

Pada tahap ini peneliti melakukan wawancara kepada beberapa orang informan untuk menggali lebih banyak tentang folklor lisan dendang dalam adat perkawinan kota Bengkulu. Pertanyaanpertanyaan spesifik tentang dendang kota Bengkulu disiapkan sebelum melakukan interview.

4. Dokumentasi

Teknik dokumentasi dilakukan dengan cara mengambil foto-foto pelaksanaan dendang dan wawancara dengan informan.

Teknik analisis data yang digunakan dalam penelitian ini adalah Teknik Alur Miles dan 
Huberman (dalam Gunawan, 2013), yang terdiri dari: 1) Reduksi Data, yakni dengan merangkum, memilih dan memilah hal-hal yang dianggap pokok dan penting. Data yang akan dirangkum adalah data tentang tahaptahap pelaksanaan dendang dan lirik serta makna dendang.; 2) Penyajian Data, dalam tahap ini dendang yang sudah ditranskripsi dan diterjemahkan kemudian diorganisasikan, diolah dan disajikan dalam bentuk uraian, dan; 3) Penarikan Kesimpulan, peneliti menyimpulkan hasil penelitian dalam upaya menjawab rumusan masalah yang sudah ditetapkan, yakni mendeskripsikan folklor lisan dendang dalam adat perkawinan kota Bengkulu.

\section{HASIL DAN PEMBAHASAN \\ Prosesi Dendang}

Dendang Tepuk Tari merupakan salah satu rangkaian seni budaya dalam adat perkawinan di kota Bengkulu. Dendang ini merupakan budaya turun-temurun dari leluhur masyarakat Bengkulu. Berdasarkan hasil wawancara dengan pelaku adat di kota Bengkulu, budaya ini mulai tergerus oleh arus perkembangan zaman. Oleh karena itu, untuk mempertahankannya diperlukan upaya yang kuat dari semua pihak, seperti masyarakat pemilik budaya dan pemerintah daerah.

Dalam prosesi dendang ini terdapat rangkaian tari tradisional khas Bengkulu dengan diiringi oleh alunan musik tradisional, serta syair-syair dendang yang dinyanyikan oleh pemain dendang. Berikut adalah urutan tari tradisional yang dipertunjukkan dalam seni dendang dalam perkawinan adat kota Bengkulu:

Tabel 1. Jenis Tarian dalam Dendang Tepuk Tari

\begin{tabular}{|c|c|c|}
\hline No. & Nama Tari & Jumlah Pemain \\
\hline 1. & Tari Rendai & Berpasangan \\
\hline 2. & Tari Sapu Tangan & Berpasangan \\
\hline 3. & Tari Gendang & Perorangan \\
\hline 4. & Tari Piring & Perorangan \\
\hline 5. & Tari Mabuk & Berpasangan \\
\hline 6. & Tari Kecik & Berpasangan \\
\hline 7. & Tari Kain Panjang & Berpasangan \\
\hline
\end{tabular}

Setiap tarian diiringi dengan syair dendang dan irama musik yang berbeda- beda. Syair dendang ini menggunakan Bahasa daerah Bengkulu. Berdasarkan hasil wawancara dengan pemain dendang, walaupun ada banyak syair yang tersedia, namun hanya ada beberapa syair yang selalu digunakan demi menghemat waktu dan kondisi. Semua syair tersebut diperoleh secara turun-temurun dan dilatih dalam komunitas seni adat Bengkulu. Namun walaupun demikian, para pemain dendang memiliki kebebasan menciptakan syair sendiri dengan tetap memperhatikan kaidah-kaidah tertentu, seperti penggunaan bahasa, kata, kalimat, dan aturan sajak, serta keselarasan topik. Selama dendang berlangsung semua pemain musik tradisional dan penyanyi duduk dengan posisi mengelilingi para penari.

Dendang pada Malam Bimbang Gedang Tepuk Tari diadakan pada malam hari ba'da Isya hingga larut malam setelah upacara akad nikah yang diselenggarakan pada siang harinya. Namun pada zaman dahulu, dendang ini berlangsung hingga adzan Subuh. Bimbang Gedang merupakan istilah dalam bahasa Bengkulu yang artinya pesta besar, sedangkan Tepuk Tari adalah nama prosesi dendang yang sarat dengan tari-tarian adat khas Bengkulu yang diiringi dengan tepuk tangan peserta dendang. Pada malam bimbang gedang ini kedua mempelai dihadirkan dengan mengenakan pakaian adat pengantin Bengkulu, dan pengantin laki-laki diminta untuk ikut menari pada sesi Tari Kain Panjang.

Prosesi dendang ini dilaksanakan di pengujung atau tarup, yakni tempat hajatan di halaman rumah pengantin dengan tiangtiang dari bambu, lantai dan dinding rendah dari papan, namun di zaman modern ini tarup dibangun menggunakan tenda dan tiang-tiang dari besi. Selain untuk prosesi seni dendang, tarup ini juga digunakan untuk aktifitas lainnya menjelang upacara pernikahan, misalnya tempat ibu-ibu memasak dan menyiapkan hidangan hajatan, serta sebagai tempat aktifitas lain seperti bermain domino atau gaplek bagi kaum bapak-bapak.

Adapun jumlah pemain dendang ini adalah sekitar 40 orang atau lebih yang 
merupakan pemain seni lokal Bengkulu. Empat orang bertugas sebagai pemain biola, satu atau dua orang sebagai pemain serunai, satu orang pemain gendang panjang dan sisanya adalah pemain rebana sekaligus sebagai penari selama dendang berlangsung. Pemain dendang rata-rata merupakan penduduk asli setempat, baik tua maupun muda, bahkan remaja dan anak-anak. Mereka tergabung dalam sanggar-sanggar yang ada di kota Bengkulu. Adapun busana yang digunakan oleh para pemain dendang adalah menggunakan jas berwarna hitam, kain sarung, dan peci hitam.

Ada tujuh macam tari yang dipertunjukkan dalam prosesi dendang secara berturut-turut. Semua tarian diiringi dengan irama musik tradisional yang berbeda-beda pada setiap tari sehingga masing-masing tarian memiliki gerakan yang berbeda-beda. Tari Rendai merupakan tari permulaan yang dilakukan di halaman tarup oleh dua orang penari. Tarian ini menampilkan gerakan silat seolah-olah mempertontonkan dua orang yang sedang bertarung. Tarian kedua adalah tari Sapu Tangan, dimana kedua penari secara berhadap-hadapan menari dengan menggunakan sapu tangan diiringi alunan serunai, gendang, rebana dengan alunan nada yang lebih pelan daripada tari Rendai. Dalam tarian ini juga terdapat alunan syair dendang dengan irama dan tempo mengikuti musik. Tarian dilakukan secara berganti-gantian oleh pasangan penari lainnya. Selanjutnya adalah Tari Gendang, yakni tarian yang dilakukan oleh satu orang penari yang menyiratkan seseorang yang sedang mencari lawan untuk bertarung. Tarian ini diiringi oleh alat musik gendang dengan irama yang cepat.

Tari Piring adalah tarian yang menggunakan properti piring dipegang oleh dua orang penari. Tarian ini memerlukan keluwesan bergerak oleh penarinya karena menjaga keseimbangan piring dengan gerakan tari. Ada empat jenis Tari Piring yang dipertunjukkan secara berturut-turut, yakni; 1) Tari Keluang Balik Tiduk, yang apabila diterjemahkan menjadi Tari Kelelewar Pulang Tidur, dimana gerakan tarinya dengan cara meliuk-liukkan kedua tangan menyerupai bentuk kelelawar, 2) Tari Tupai Begelut, yakni tarian dengan gerakan seperti tupai yang meloncat-loncat seolaholah sedang bergelut, 3) Tari Hari Pane Tudung Pinggan, yang bermakna tarian di hari panas tudung piring, sehingga dalam tarian ini ada gerakan mengangkat salah satu tangan sedang melindungi kepala dari terik matahari, 4) Tari Ngasib Mertuo Makan, artinya tari memberi makan makan mertua, yakni tarian dengan gerakan seolah-olah sedang mempersembahkan makanan kepada orang yang dituakan. Dalam tari piring ini, sebuah cincin terbuat dari besi disematkan di salah satu jari penari yang berbunyi ketika terkena piring sehingga menimbulkan irama-irama yang khas. Berikutnya adalah Tari Mabuk yang mempertontonkan gerakan orang mabuk, Tari Kecik atau tari kecil yang dilakukan oleh dua orang penari namun hanya dua hentakan gerakan (sedikit sehingga disebut tari kecil). Sebagai tarian penutup adalah Tari Kain Panjang, yakni tarian yang menggunakan selendang panjang. Semua rangkaian tari tersebut tidak dilaksanakn secara sekaligus. Tarian-tarian dijeda dengan jamuan makan, yakni jamuan nasi santan (nasi lemak) dan kue-kue makanan khas kota Bengkulu.

\section{Kajian Bentuk}

Dilihat dari segi bentuknya, syair dendang dalam adat perkawinan kota Bengkulu ini adalah berbentuk pantun. Ada dua jenis pantun yang digunakan, yakni; pantun biasa dan talibun. Berikut adalah contoh pantun biasa yang ditemukan dalam dendang perkawinan adat di Bengkulu:

Anak ikan dimakan ikan
Anak tenggiri dalam laut
Sanak bukan saudara bukan
Karno budi mangko tersangkut
Dari Manna ke Padang Guci
Singgah memasak di Dusun Kedurang
Adik belarak aku tangisi
Tinggallah badan sebatang karang

Anak ikan dimakan ikan

Anak tenggiri dalam laut

Sanak bukan saudara bukan

Dari Manna ke Padang Guci

Singgah memasak di Dusun Kedurang

Tinggallah badan sebatang karang 
Jurnal Pendidikan Bahasa dan Sastra, Volume 20, Nomor 1, April 2020, pp. 84-94

Kalu ado kaco di pintu

Jambak sayo merabkan

Kalu ado kato yang sungguh

Nyawa dan badan aku serabkan

Petang kami malam Jumat

Pasang pelito di atas peti

Kalu rindu panggil semangat

Mandang bertemu dalam mimpi

Kapal kecik ndak berlayar

Kapal gedang sedang muek kayu

Dari kecik idak belajar

Mangko la gedang idak pulo ndak beguru

Buah mengkudu banyak getahnyo

Apolagi cempedak mudo

Lagi yang tuo-tuo banyak salahnyo

Apo lagi yang mudo-mudo

Pantun-pantun yang digunakan dalam adat dendang perwakinan di kota Bengkulu adalah pantun biasa yang tersusun atas empat baris atau lebih dalam tiap baitnya, dua baris pertama merupakan sampiran dan dua baris berikutnya merupakan isi. Pantunpantun tersebut menggunakan sajak akhir ab-ab, dimana baris 1 dan 3 memiliki akhir yang sama, begitu juga dengan baris 2 dan 4 . Selain itu ada juga pantun yang menggunakan sajak akhiran aa-aa, yakni semua baris memiliki akhiran yang sama, misalnya terlihat pada pantun terakhir yang semua akhirannya adalah oo-oo. Pantunpantun tersebut didendangkan secara acak, tidak harus berurutan. Sifatnya tidak saling berbalas pantun.

Selain berbentuk pantun biasa, syair dendang ini juga berbentuk talibun. Menurut Nursisto (2000,p.11-14), pantun talibun merupakan puisi lama yang ciricirinya sama dengan pantun lain karena memiliki sampiran dan isi, namun terdiri dari 6, 8, atau lebih baris pantun dalam 1 bait (dalam hitungan genap). Talibun yang ditemukan dalam dendang adat perkawinan kota Bengkulu terdiri atas delapan baris dengan sajak akhir yang teratur. Talibun yang didendangkan oleh pendendang 1 memiliki sajak akhir ab-ab. Talibun kedua merupakan talibun balasan dari talibun 1 .
Contoh talibun yang berhasil dihimpun dalam dendang adat perkawinan kota Bengkulu adalah sebagai berikut;

Pendendang 1

Kami anak dalam kota Bengkulu

Putri bernamo gading cempako

Kubarap doa dari jau

Lambek laun bertemu jugo

Putri bernamo gading cempako

Tempek tinggalnyo di pantai Panjang

Lambek. laun bertemu jugo

Asal kawan berumur Panjang

Pedendang 2

Tempek tinggalnyo di pantai Panjang

Haluan menuju kualo lempuing

Asal kawanku berumur Panjang

Cintomu tuan jgn berpaling

Haluan menuju kualo lempuing

Sayup memandang kualo baru

Cintomu tuan jgn berpaling

Kubarap kasib dendam bertemu

Dari segi bentuk, terlihat adanya unsur pengulangan (repetition) dalam talibun tersebut. Tidak hanya pengulangan kata, namun juga terdapat pengulangan kalimat. Misalnya pada talibun 1, terdapat pengulangan kalimat putri bernamo Gading Cempako pada baris ke-5 yang juga ditemukan pada baris ke-2. Hal itu juga diulangi pada baris ke-1 pada talibun ke-2 (syair balasan). Pengulangan ini dimaksudkan untuk mempertahankan topik yang sedang dibicarakan dalam syair, karena talibun dalam dendang ini sifatnya saling berbalas kalimat. Talibun dianggap gagal apabila terdapat syair yang topiknya tidak sejalan dengan talibun sebelumnya. Sebagai konsekuensinya, syair dendang diambil alih oleh pedendang lainnya. Hal ini dianggap sebagai "bumbu" dalam prosesi dendang yang dapat memeriahkan acara.

Dalam proses dendang ini, talibun yang didendangkan oleh pemain tidak terikat pada satu atau dua buah talibun. Pemain dendang bebas mengeksplorasi kemampuan masing-masing untuk saling berbalas talibun. Talibun yang digunakan bisa berjumlah 6 baris, 8 baris, atau 10 baris 
sesuai dengan kemampuan pendendangnya dalam menyusun kalimat.

Dendang dalam adat perkawinan Bengkulu memiliki bentuk yang berbeda dengan dendang Banjar Hulu (Marfuah, 2014). Dendang Banjar Hulu berbentuk pantun dan puisi bebas, yakni dalam bentuk pantun kilat (karmina) yang tersusun atas 2 baris dalam 1 bait. Namun penelitian tersebut tidak menganalisis tentang prosesi dendangnya. Namun pantun dalam adat perkawinan di Bengkulu memiliki ciri-ciri yang sama dengan pantun adat perkawinan di Serawai kota Manna Bengkulu Selatan, yakni terdiri dari 2 baris pertama yang berkisah tentang alam dan 2 baris berikutnya berisi tentang manusia (Tarmizi, 2012). Dari segi isi, pantun-pantun dalam adat perkawinan Serawai terdiri dari pantun nasihat, pantun muda-mudi (berkasih sayang), pantun beriba hati, dan pantun jenaka.

Dilihat dari segi diksi yang digunakan, baik pantun maupun talibun mengandung hal-hal yang berhubungan erat dengan kehidupan masyarakat Bengkulu. Berdasarkan teori ruang persepsi manusia Halley (dalam Wahab, 1998), diperoleh beberapa kategori diksi dalam dendang adat perkawinan Bengkulu, antara lain (1) diksi kategori being, (2) diksi kategori terresterial, (3) diksi kategori living, (4) diksi kategori animate, dan (5) diksi kategori buman.

Berdasarkan hasil analisis data, kategori being yang berarti kategori diksi yang bersifat abstrak ditemukan baik dalam pantun maupun talibun. Misalnya pada katakata do'a, cintomu, kasih, dendam, budi, rindu, dan mimpi. Kata-kata tersebut memiliki makna yang tidak dapat dijangkau oleh indera manusia dan memiliki makna tersendiri bagi masyarakat Bengkulu yang masih memegang teguh nilai-nilai moral kehidupan yang erat kaitannya dengan kasih saying. Untuk kategori terresterial yang bermakna ada dan terhampar di bumi, ditemukan pada kata-kata kualo, pantai, dan laut. Kualo atau kuala merupakan pertemuan sungai dengan laut (KBBI). Kata-kata pantai muncul beberapa kali dalam syair dendang Bengkulu karena kota Bengkulu merupakan daerah pesisir pantai, dan memiliki pantai yang dikenal dengan Pantai Panjang, dengan garis pantai mencapai $7 \mathrm{~km}$ dan lebar sekitar 500 meter.

Kategori living juga ditemukan dalam pantun dan talibun dendang. Living artinya tumbuh, yang erat kaitannya dengan alam dan tumbuh-tumbuhan. Dalam dendang ini ditemukan kata buah-buahan, seperti buah mengkudu dan buah cempedak. Buah-buahan tersebut merupakan buahbuahan yang banyak ditemukan di hutan Sumatra, terutama Bengkulu. Untuk kategori animate (hewan) ditemukan katakata ikan, dan tenggiri. Hal tersebut memberikan simbol hasil alam Bengkulu dari hasil lautnya, yakni berbagai jenis ikan laut. Syair dendang ini juga mengandung diksi dengan kategori buman (manusia), yakni hal-hal yang erat kaitannya dengan manusia dengan beragam aktifitasnya. Contohnya, kata-kata makan, memasak, tangisi, berlayar, belarak dan sebagainya. Berlayar merupakan simbol aktifitas para nelayan di Bengkulu ketika berlayar mencari ikan di lepas pantai Bengkulu. Sementara kata belarak merupakan kegiatan menggiring pengantin di jalan raya sebagai salah satu rangkaian adat pernikahan kota Bengkulu.

\section{Kajian Fungsi}

Berdasarkan teori Alan Dundes dan William R. Bascom (dalam Sudikan, 2001,p. 109-112), ada beberapa fungsi dari dendang dalam perkawinan adat kota Bengkulu, yaitu: 1) sebagai sarana hiburan, 2) sebagai jati diri masyarakat, 3) sebagai kritik sosial, dan 4) sebagai sarana mendidik.

Fungsi pertama sebagai sarana hiburan. Prosesi ini merupakan salah satu acara hiburan dalam rangkaian prosesi adat pernikahan di Bengkulu. Hal ini terlihat dari sejumlah tari-tarian yang dipertontonkan, kegiatan berbalas pantun yang dapat memeriahkan suasana, dan irama musik tradisional yang dapat mengajak para penontonnya untuk ikut menari dan bertepuk tangan bersama.

Fungsi kedua, dendang ini berfungsi sebagai jati diri masyarakat. Masyarakat Bengkulu memegang teguh adat-istiadat. 
Dendang adalah bagian dari jati diri msyarakat Bengkulu, yang mencerminkan identitas dan ciri khas masyarakatnya, memperjelas identitas leluhur dari raja-raja yang ada di Bengkulu yang bernama Putri Gading Cempaka. Selain itu, dalam syair dendang tersebut juga menjelaskan identitas masyarakat Bengkulu yang berada di pesisir pantai dan kaya akan hasil lautnya. Dendang ini juga mencerminkan pola bergaul masyarakat Bengkulu, seperti setia memegang janji.

Misalnya dalam kutipan kalimat:

\section{Kalu ado kato yang sungguh nyawo dan badan aku serabkan}

Artinya: Kalau ada kata-kata yang sungguh (janji), maka nyawa dan badan saya pertaruhkan.

Fungsi berikutnya adalah sebagai kritik sosial sekaligus mendidik. Dendang ini juga digunakan sebagai sarana untuk mengkritisi fenomena-fenomena sosial dalam pergaulan masyarakat Bengkulu. Hal ini terpapar jelas dalam baris pantun dalam dendang.

Misalnya:

\section{Sanak bukan saudara bukan}

Karno budi mangko tersangkut

Terjemahan:

Saudara bukan keluarga bukan

Karena budi sehingga tersangkut

Kutipan itu mengandung pesan bahwa, walaupun tanpa adanya ikatan keluarga, budi bahasa dan akhlak yang mulia akan mampu menjadi ikatan persaudaraan. Hal ini memberikan simbol pola hidup kekeluargaan yang terjalin di tengah-tengah masyarakat Bengkulu, terbukti dari adat dan kebiasaan berkumpul bahu-membahu saling membantu pada saat mempersiapkan acara pernikahan sejak satu minggu sebelum hari pernikahan, misalnya bersama-sama memasak dan menyiapkan jamuan hingga menegakkan tarup untuk acara akad nikah dan resepsi pernikahan. Kutipan itu juga mengandung kritik terhadap masyarakat yang sering memutuskan tali silaturahmi dalam keluarga sendiri sekaligus memberikan pesan agar senantiasa menjalin kebersamaan dalam masyarakat.
Kritik sosial berikutnya terdapat dalam kutipan berikut:

Dari kecik idak belajar

Mangko la gedang idak pulo ndak beguru

Terjemahan:

Dari kecil tidak belajar

Ketika besar tidak juga mau berguru

Kutipan itu mengandung kritik terhadap masyarakat yang tidak memiliki inisiatif untuk menuntut ilmu sejak dini. Fenomena ini sering dijumpai dalam masyarakat, termasuk Bengkulu.

Kutipan berikutnya adalah:

$$
\begin{aligned}
& \text { Lagi yang tuo-tuo banyak salabnyo } \\
& \text { Apo lagi yang mudo-mudo } \\
& \text { Terjemahan: }
\end{aligned}
$$

Sedangkan yang tua banyak salahnya

Apalagi yang muda

Kutipan itu mengandung kritik sekaligus pesan terhadap anak-anak muda yang masih perlu menimba ilmu dan mencari pengalaman sebanyak-banyaknya. Selain itu, kalimat tersebut juga mengandung pesan kepada masyarakat untuk terus belajar tanpa harus menimbang umur.

Fungsi adat dendang perkawinan Bengkulu memiliki kemiripan dengan fungsi dendang Banjar Hulu (Marfuah, 2014), namun Dendang Banjar Hulu memiliki fungsi lain, yakni berfungsi membangkitkan semangat dan menggungah motivasi. Dendang dalam adat perkawinan Bengkulu lebih dominan berfungsi sebagai kritik sosial dibandingkan dengan fungsi dendang adat perkawinan di Bengkulu Selatan yang cenderung hanya berfungsi sebagai hiburan, komunikasi, dan sebagai integrasi dalam masyarakat (Tarmizi, 2010,p.48).

\section{Kajian Nilai}

Dari aspek nilai, dendang dalam perkawinan adat kota Bengkulu mengandung nilai-nilai tertentu, yaitu: 1) nilai filosofis, adalah nilai yang merupakan representasi dari pandangan-pandangan hidup berupa kebijakan-kebijakan dalam menjalani kehidupan bagi warga kota Bengkulu secara turun-temurun, 2) nilai religius, adalah nilainilai agama yang merupakan pedoman 
hidup bagi masyarakat kota Bengkulu yang erat kaitannya dengan hubungan manusia dengan Tuhan dan 3) nilai sosiologis, adalah nilai-nilai kehidupan bermasyarakat warga Bengkulu yang direfleksikan dalam bentuk perilaku, sifat, kebiasaan dalam berinteraksi satu sama lain antar warga agar tercipta hubungan sosial masyarakat yang rukun dan harmonis.

Dari hasil analisis data yang diperoleh, dendang dalam adat perkawinan kota Bengkulu ini mengandung nilai-nilai yang mencerminkan budaya dan norma-norma masyarakat Bengkulu, antara lain: pertama, nilai filosofis, yakni menyangkut pandangan hidup, keyakinan, kebijakan yang menentukan arah, prilaku, maupun sikap masyarakat. Nilai filosofis ini ditemukan dalam kutipan kalimat Kalu ado kato yang sungguh, nyawa dan badan aku serabkan. Kutipan tersebut mengandung nilai keteguhan hati dalam memegang janji, baik kata-kata maupun tindakan.

Kedua, dendang ini juga mengandung nilai religi atau keagamaan (hubungan manusia dengan Tuhan). Hal itu tercermin dalam kalimat Kubarap doa dari jau, lambek laun bertemu jugo, yang artinya kuharap do'a dari jauh, lambat laun akan bertemu juga. Dalam kalimat tersebut jelas terlihat bahwa adanya unsur religi dengan adanya kata do'a atau pinta kepada Tuhan agar terkabulkannnya suatu harapan. Masyarakat Bengkulu merupakan masyarakat Melayu di pulau Sumatra yang sebagian besar penduduknya beragama Islam dan memegang teguh syariat Islam. Upacara adat perkawinan di Bengkulu diwarnai oleh nuansa Islamik (Samsudin, 2018: 89). Hal ini juga tercermin dalam berbagai adat budaya hingga upacara keagamaan di Bengkulu yang selalu menggunakan nuansa Islamik, misalnya kain khas Batik Besurek yang bermotif huruf Arab, upacara sunat rasul, upacara menyambut kelahiran anak, upacara pembuangan Tabot pada tanggal 1 Muharram hingga 10 Muharram, acara syukuran menjelang puasa atau lebaran dan upacara lainnya. Di samping syairnya, prosesi dendang ini juga mengandung nilai keagamaan. Hal itu tercermin dari seragam yang dikenakan oleh para pemainnya, yakni sarung dan peci.

Nilai ketiga adalah nilai sosiologis yang erat kaitannya dengan cara bergaul masyarakat. Nilai ini tercermin dalam kalimat sanak bukan saudara bukan, karno budi mangko tersangkut, yang mengandung nilai sikap dan prilaku yang baik akan mempererat silaturahmi dalam masyarakat. Lalu kalimat adik belarak, tinggallah badan sebatang karang, yang artinya adik menikah (diarak), tinggallah diri seorang. Kalimat itu mengandung makna kasih sayang, rasa kehilangan, baik kasih sayang dalam keluarga maupun kasih sayang dengan pasangan. Lalu kalimat lagi yang tuo banyak salabnyo, apolagi yang mudo-mudo mengandung nilai kritik sosial untuk meningkatkan pengetahuan, pengalaman, serta ruang lingkup pergaulan dalam masyarakat agar dapat membedakan mana yang baik mana yang tidak baik.

Dapat disimpulkan bahwa nilai-nilai yang terkandung dalam adat dendang perkawinan Bengkulu merupakan kombinasi dari nilai sosial budaya Melayu dan nilai-nilai Islam. Hal ini sejalan dengan hasil penelitian Samsudin (2018: 90) yang menyimpulkan bahwa adat perkawinan di Bengkulu merupakan perpaduan antara nilai budaya dan nilai agama, yakni agama Islam. Dendang adat perkawinan Bengkulu ini juga memiliki nilai yang sama dengan pantun dendang Suku Serawai kota Manna Bengkulu Selatan (Tarmizi, 2012), dimana ditemukan bahwa dendang Perkawinan suku Serawai mengandung nilai Pendidikan, moral, estetis, dan sosial.

\section{SIMPULAN}

Dendang pada malam bimbang gedang Tepuk Tari ini merupakan sebuah prosesi adat yang terdiri dari tarian dan nyanyian yang diiringi dengan musik tradisional Bengkulu. Ada tujuh macam tarian yang ditampilkan dalam dendang ini, yakni; Tari Rendai, Tari Sapu Tangan, Tari Gendang, Tari Piring, Tari Mabuk, Tari Kecik, dan Tari Kain Panjang. Tari-tarian tersebut ditampilkan secara beurutan dan diselingi dengan syair dendang. Syair dendang tersebut tersusun dalam bentuk pantun, 
yakni pantun biasa dan talibun. Sama halnya dengan pantun biasa lainnya, pantun dalam syair dendang ini terdiri dari 4 baris dalam 1 bait dengan sajak aa-aa atau ab-ab, 2 baris pertama merupakan sampiran dan 2 baris kedua merupakan isi. Sementara talibun dalam dendang ini terdiri dari 6 atau 8 baris lebih dalam 1 bait. Talibun ini dilakukan secara berbalasan dengan prinsip tetap mempertahankan topik yang sedang dibicarakan. Sementara diksi yang digunakan dalam syair dendang ini terdiri dari diksi kategori; being, terrestrial, living, animate, dan human. Dilihat dari segi fungsi, dendang ini memiliki fungsi sebagai: 1) sarana hiburan, 2) jati diri masyarakat, 3) kritik sosial, dan 4) sarana mendidik. Sementara dari segi nilai, dendang ini sarat akan nilai-nilai filosofis, religi, dan sosiologis yang mencerminkan prinsip-prinsip yang dipegang teguh oleh masyarakat Bengkulu dalam berprilaku, bertindak, mengambil keputusan, dan bergaul dalam masyarakat.

\section{DAFTAR RUJUKAN}

Adat dan Upacara Perkawinan Daerah Bengkulu. (1995). Proyek Penelitian \& Pencatatan Kebudayaan Daerah. Bengkulu: Departmen Pendidikan dan Kebudayaan Kantor Wilayah Provinsi Bengkulu.

Asri. (2008). Ungkapan dalam Perkawinan Adat Suku Moronene. Kendari: Kantor Bahasa Provinsi Sulawesi Tenggara.

Astika, M. I., \& Yasa, I. N. (2014). Sastra Lisan Teori dan Penerapannya. Singaraja: Graha Ilmu.

Bertens, K. (2004). Etika. Jakarta: PT Gramedia Pustaka Utama.

Danandjaja, J. (1986). Foklor Indonesia, Ilmu Gosip, Dongeng dan lain-lain. Jakarta: Grafiti Press.

Effendi, et al. (1998). Perubaban Nilai Upacara Tradisional pada Masyarakat Pendukungnya (Upacara Adat Perkawinan Suku Bangsa Lembak di Kotamadya Bengkulu). Bengkulu: Departemen Pendidikan dan Kebudayaan RI.

Gunawan, I. (2013). Metode penelitian kualitatif. Jakarta: Bumi Aksara.
Marfuah, M. (2014). Kajian Bentuk, Makna, Dan Fungsi Dindang (Form, Meaning, and Function Analysis of Dindang). Jurnal Bahasa, Sastra dan Pembelajarannya (JBSP), 4(2), 313-324.

Marwati, A. (2017). Ungkapan Tradisional dalam Upacara Adat Perkawinan Masyarakat Bajo di Pulau Balu Kabupaten Muna Barat. Jurnal Humanika, 3(15).

Nursisto. (2000). Ikbtiar Kesusastraan Indonesia. Yogyakarta: Adi Cita.

Perda Kota Bengkulu. (2005). Adat Kota Bengkulu. Bengkulu: Bagian Hukum Setda Kota Bengkulu.

Ricouer, P. (2002). The Interpretation Theory, Filsafat Wacana Membaca Makna dalam Anatomi Bahasa. Yogyakarta: IRCiSoD.

------.(2006). Hermeneutika Ilmu Sosial. (Terjemahan Muhammad Syukuri). Yogyakarta: Kreasi Wacana.

Samsudin, S. (2018). Upacara Adat Perkawinan Bengkulu (Analisis Filosofis, Nilai Islam dan Kearifan Lokal). Nuansa, 11(2).

Sudikan, S.Y. (2001). Metode Penelitian Sastra Lisan. Bandung: Citra Wacana.

Takari, M. (2014). Adat Perkawinan Melayu Gagasan Terapan dan Fungsinya. Medan: USU Press.

Tarmizi, P. (2010). Fungsi Kesenian Dendang dalam Upacara Adat Perkawinan di Desa Gunung Ayu Kota Manna Bengkulu Selatan. Jurnal Penelitian UNIB, 16(1), 48-55

Tarmizi, P.(2012). Tafsir Nilai-Nilai melalui Pantun Dendang Suku Serawai di Kota Manna Bengkulu Selatan. Diakses dari: http://repository.upi-edu/id/ eprint/9562.

Wahab, A. (1998). Isu Linguistik: Pengajaran Bahasa dan Sastra. Surabaya: Airlangga University Press.

Waskita, D., \& Sulistianingtyas, T. (2011). Sastra Lisan sebagai Kekuatan Kultural dalam Pengembangan Strategi Pertahanan Nasional di Pelabuhan Ratu Jawa Barat. Jurnal Sosioteknologi, 10(23), 1093-1102. 